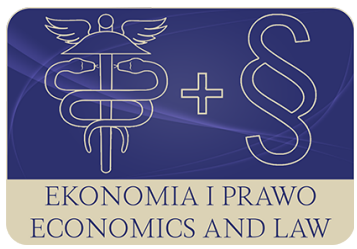

EKONOMIA I PRAWO. ECONOMICS AND LAW

Volume 16, Issue 3, September 2017

p-ISSN 1898-2255, e-ISSN 2392-1625

www.economicsandlaw.pl

received 13.06.2017; revised 16.09.2017; accepted 30.09.2017 Citation: Badzińska, E. (2017). Assessing the concept of innovative business model with regard to IT enterprise. Ekonomia i Prawo. Ecomomics and Law, 16(3): 245-258. doi:10.12775/EiP.2017.017.

\title{
Assessing the concept of innovative business model with regard to IT enterprise
}

\author{
EWA BADZIŃSKA \\ Poznań University of Technology, Faculty of Engineering Management, Department of Economic \\ Sciences, ul. Strzelecka 11, 60-965 Poznań, Poland \\ $\square$ ewa.badzinska@put.poznan.pl
}

\begin{abstract}
Motivation: The complexity and dynamic changes of external conditions necessary for enterprises to function and increased competition in the local and global markets impose constant search for the most effective business model for the development of organizations. Its accurate identification and measurement influence the utilization of internal capacity of organizations, market opportunities and application of adequate instruments of competition.

Aim: The purpose of this study is to perform a synthesis of the theoretical framework concerning business models. The empirical part presents the conceptualization and descriptions of a real business model. It has been developed by a Polish IT (information technology) enterprise for the implementation of modern technological-programming solutions on the international market. Particular attention is paid to the potential of intellectual resources and the value proposition offered by the enterprise.

Results: The research findings reveal the existence of interdependencies between intellectual potential of staff members and success in business practice. By creating and implementing innovative business model, the enterprise must take into account the context of micro-business as well as social, economic and political environments in which it operates and the goals and mission of its activity. The conducted research attempts to explain the concept of an innovative business model and confirms that domestic market often

turns out to be too small for the needs of growing young technology enterprises.
\end{abstract}

Keywords: business models; entrepreneurship; intellectual potential; technology enterprise JEL: O21; O31; O32; O33 


\section{Introduction}

Young and innovative companies, particularly those operating in the information technology (IT) sector, often decide to offer their services abroad. Export of goods and services constitutes an important aspect of their development. Domestic market often turns out to be too small for the needs of growing companies in the IT sector. Enterprises are looking for broader perspectives, new business partners as well as engaging promising projects, which involve the need to present their offer in foreign markets. This determines the development of innovative and sustainable business models because organizations are forced to compete with new and often more innovative entities.

The phenomena that take place in contemporary economy contribute to the creation of a new framework that is mapping the fundamental assumptions of success, constitute the foundations of currently adopted business models (Jabłoński, 2009, pp. 27-37). Societies should be looking for a new balance which would reconcile short-term profitability and long-term durability. Innovative business models are the subject of theoretical analysis and practical implementation. They should adequately suit the needs of contemporary business practice (Raczkowski et al., 2016, pp. 123-150).

The conceptualization of an innovative and sustainable business model is a complex phenomenon that encompasses not only multiple levels of analysis to be investigated using different perspectives, but also a case-by-case approach for the analysis to be meaningful. The business model concept still needs explanation in a rapidly changing environment.

The scientific purpose of this study is to compile the views of scholars on business model concept. Attention is paid to a widely accepted conceptual apparatus and the multidimensionality of this phenomenon. The paper refers to both Polish and foreign literature concerning the notion of business models. The paper identifies the terminology used to describe a business model and try to build the foundations to clarify understandings in the business model concept.

The empirical part of the paper presents the conceptualization and descriptions of a real business model. It has been developed by a young Polish enterprise for the implementation of a service for creating modern technological-programming solutions in the United Kingdom (UK) market. For this purpose, Business Model Canvas template by Osterwalder and Pigneur (2010, pp. 1644) has been used. The application of the empirical method of a case study has made it possible to characterize the essence of creating an innovative business model. Particular attention was paid to the potential of intellectual resources and the value proposition offered by the enterprise on the international market. Creative and innovative entrepreneurship involves processes through which organizations generate value from their intellectual capital and knowledge-based assets (Badzińska, 2017, pp. 46-64). This paper may provide a starting point for an in-depth empirical research and contribution to the discussion on the methodological dilemmas associated with conducting research in this area. 


\section{Business model concept: theoretical background}

A review of the literature shows a broad diversity of understandings, usages, and places of business model concept in business practice. The multidimensionality of this phenomenon raises a number of difficulties in assessing a widely accepted definition. The topic of business models is discussed in various different domains, such as designing and evaluating e-business models, information systems, strategy, and management (Applegate, 2001, pp. 79-87; Dubosson-Torbay et al., 2001, pp. 5-23; Gordijn et al., 2001, pp. 7-11; Szpringer, 2012, pp. 67-82). The popularity of the term 'business model' is a relatively new phenomenon. Initially, the notion of a business model was used in the context of data and process modelling for IT systems (Konczal, 1975, pp. 12-15). It rose to prominence towards the end of the 1990s and was often used in relationship with the Internet (Osterwalder et al., 2005, pp. 7-9). That is, the business design choices for managers increased substantially based on cheaper available information technology.

The starting point for defining the notion of business model and proposing the operationalization of this term can be the interpretation by Osterwalder et al. (2005, p. 5). The authors argue that a business model is a conceptual tool containing a set of objects, concepts and their relationships with the objective to express the business logic of a specific firm. Additionally an innovative business model is manifested in unique solutions, added value proposition, in introducing new products and technologies as well as in unconventional problem solving. One useful way of thinking about an innovative approach to creating a business model is concerned with understanding how the business model concept could become an important tool to further develop and improve existing methods of business (Osterwalder \& Pigneur, 2003).

The conceptualization of an innovative and sustainable business model is complex phenomenon that encompasses multiple levels of analysis. From a company perspective, it can be distinguish between a more value / customer oriented approach, a activity / role related definition as well as a conceptual / tool approach. These different viewpoints refer to the conceptualization of the way a company does business in order to reduce complexity to an understandable level. In other words, for business models, the quest is to identify the elements and relationships that describe the business a company does. A multitude of tools and concepts should help companies and their managers specify their business model. An attempt to perform a synthesis of the theoretical framework concerning business models is presented synthetically in Table 1.

Nowadays global social, environmental, political, and technological trends shape the foundations of current business models. Regardless of the accepted definition, it is most common to include into the business model the Corporate Social Responsibility (CSR) of companies (Berger et al., 2007, pp. 132-157; Claydon, 2011, pp. 405-420). This novel approach to a business model provides new directions of business activities that are focused not only on the objective 
of profit maximization and value creation, but also on acting in a 'responsible' way for society.

The next reflection concerns the business model implementation and execution, because it is conceptually to distinguish between model (i.e. the business concept) and implementation (i.e. the form it takes in reality). Business model implementation and management include the 'translation' of the business model as a plan into more concrete elements, such as a business structure, business processes as well as infrastructure and systems (Brews \& Tucci, 2003, pp. $8-22)$. Some authors call this relation between strategy, organization, and systems the business triangle (Osterwalder et al., 2005, p. 14). It is constantly subject to external pressures, like competitive forces, social and technological changes, customer opinion and legal environment.

Based on the literature synthesis leading to identify the most common building blocks among business models Osterwalder et al. (2005, pp. 17-18) propose the following definition: A business model is a conceptual tool that contains a set of elements and their relationships and allows expressing the business logic of a specific firm. It is a description of the value a company offers to one or several segments of customers and of the architecture of the firm and its network of partners for creating, marketing, and delivering this value and relationship capital, to generate profitable and sustainable revenue streams.

According to Osterwalder and Pigneur (2010) a business model describes the essential building blocks and their relationships that should help managers to design a sustainable business model. It can be distinguished between: customer interface, infrastructure management, and financial aspects. Customer interface contains four building blocks, namely (i) value proposition - gives an overall view of a company's bundle of products and services, (ii) target customer - describes the segments of customers a company wants to offer value to, (iii) distribution channel - describes the various means of the company to communicate with its customers, (iv) relationship - explains the kind of links a company establishes between itself and its different customer segments. In turn, infrastructure management includes (i) the arrangement of activities and resources, (ii) core competencies necessary to execute the company's business model, (iii) partner network of cooperative agreements with other companies necessary to efficiently offer and commercialize value. And finally financial aspects contain (i) cost structure as the monetary consequences of the means employed in the business model, (ii) revenue streams that describes the way a company maximizes profits through a variety of revenue flows.

Designing a coherent business model where all the elements are mutually reinforcing or at least optimized individually is not an easy task. Because business models are quite complex, their success is often based on the interaction of a number of apparently minor elements. 


\section{Methods of the research}

The first part of the paper is both theoretical and analytical. A review of scientific literature has been conducted along with the analysis of secondary research results on the nature of business models. Attention has been drawn to the concept and the characteristics of this phenomenon. The following methods were used: defining, comparing, attribute analysis, inference. A further part of the study is empirical in its nature as it is based on a qualitative case study analysis of a technology firm. The cognitive aim is to identify the potential of intellectual resources and the value proposition offered by the IT enterprise on the international market.

In order to ensure the reliability of data, the triangulation principle was adopted. The logic is based on the fact that a single method can not adequately solve the problem of rival causal factors (Jick, 1979, pp. 602-611). The confrontation of multiple data sources justifies the cyclical nature of data collection procedures in the case under examination. Qualitative data was obtained from in-depth interviews conducted with three owners of the IT enterprise, who are responsible for its development on the perspective UK market. An interview questionnaire was prepared. Semi-structured interview guide contained the following questions (i) general about the company and its organizational structure, (ii) about all innovation products and projects, (iii) about value propositions and new customer segments, (iv) about the sources of financing innovative projects as well as the cooperation with business environment institutions and enterprises on the UK market. To expand the database on the company an analysis of materials from available secondary sources was also conducted. They included websites, publications and opinions of cooperation partners.

The wide problem area of innovative and sustainable business models requires the acceptance of the limitations of the study. The empirical method uses a case study involving the analysis of processes implemented in the selected enterprise (Dyer \& Nobeoka, 2000, pp. 345-367). The rationale for the use of a case study is its usefulness related to the timeliness of the analyzed phenomenon and the dynamism of its effects (Yin, 1984). There is a need to conduct a practice-oriented empirical research to help managers for a better allocation of re-sources and better efficiency in general (Czakon, 2013, pp. 92-113; Salerno et al., 2015, pp. 59-70). The studied technology enterprise was selected with a purposeful sampling technique (Merriam, 1998; Maxwell, 2005). The purposeful selection of MindsEater resulted from the following (i) the pragmatic criterion of availability of data, (ii) clarity of the explained phenomenon of innovative business model, (iii) the identified unique value proposition. The applied case study has helped to recognize the studied phenomenon under real conditions. Both descriptive and explanatory techniques were used in the presented case study. 


\section{Research results and discussion}

The subject of the study is a young technology enterprise that has been on the market since 2013. In its Information and Communication Technologies (ICT) solutions the company uses new tools of communication and focuses on the customization of technological-programming services dedicated to individual business customer needs. Entrepreneurs from MindsEater are characterized by an approach to use of latest IT technology. The involvement of the team, a shared vision of the present and the future of the company constitute the basis for its development on global market. The creativity, capabilities, dynamism, and innovativeness of the entrepreneurs in a country are important aspects of the absorptive capacity, which is such a distinctive characteristic of successful development experiences (Szirmai et al., 2011). According to Foss and Klein (2012, p. 69) an entrepreneur has to be alert, creative, and leader - and not some abstract, hypothetical discoverer - who is the driving force of the market. Entrepreneurship is seen as a process of searching for market opportunities and organizational resources necessary to exploit these opportunities to gain results in the long term. It can be distinguished as independent risk taking ability to achieve the biggest profits in the market (Nacu \& Avasilcai, 2014, p. 229-235).

External funding of the innovative platform ITProjectPlace (2017), created by MindsEater 2014 with support from the European Regional Development Fund under the OPIE 8.1., has enabled the company to develop its range of online services and support customers in the implementation of projects, which resulted in further development of the company. A team of MindsEater is planning a continued development of the innovative platform and expand operations to international markets, including the British market. Through dedicated applications, providing customers with a series of comprehensive IT tools and individual counseling the company is helping to identify and create opportunities for other economic agents.

Currently, MindsEater is engaged in the implementation of broadly defined ICT solutions - from websites and portals ranging through business applications, online shops, to a variety of innovative ideas related to the IT industry and modern mobile technologies. The team of MindsEater designs portals and Internet applications for their clients, and also provides support and IT consulting to other entities. The company focuses mainly on larger projects (including international ones), which are usually carried out over a period of several months to over a year. It places great emphasis on the understanding of customer needs, partnership in business relations and preparing solutions that are best suited to the specific nature of business.

A dominating factor, which determines the company's market position is its know-how regarding the construction of dedicated IT systems and the competence of the employed team. They are experienced programmers, focusing 
on the creation and promotion of innovative projects based on advanced solutions and requiring expertise in programming.

The company's commitment to the development of export to the British market stems from its desire for self-development and growing importance in the international arena. The process of spreading activities across other countries can not only provide tangible economic benefits, primarily related to the diversification of the sources of income, but also increase its value and image on the domestic market. An important goal in the development of exports is to strengthen the company's position on the international market and increase its online market share. The company's activity focused on foreign markets should contribute to building a positive company image — a robust and a reliable one, characterized by high quality of IT services.

\section{The conceptualization of an innovative business model}

The business model describes the way in which organizations create value and profit from it. By simplifying and clarifying the described reality the business model allows entrepreneurs to make better decisions and increases efficient management. Fundamental to the concept of an innovative business model is to establish a common definition of the model and develop a comprehensive, factually adequate concept. This allows verifying assumptions, systematically regarding own business model and formulating subsequent tasks and alternatives.

In order to obtain an answer to the research question on the kind of resources necessary for a company to create and implement innovative business model on the international and perspective British market, an attempt has been made to diagnose such a potential and unique value in the analyzed enterprise. The competence of the company to compete internationally depends on a set of endogenous and exogenous factors. The obtained results and the concept of an innovative business model are presented synthetically in Table 2 using Canvas Model template ${ }^{1}$. This model's template has been designed as the sum of resources and activities, which a company organizes and implements in order to provide a specific value for a particular client. The elements of the business model concern essential, interdependent areas of the company's business activity.

The designed business model for the technology enterprise is an example of a hybrid model - it combines the characteristics of the manufacturer's model, buyers' broker, transaction broker and the model of virtual community (Andries \& Debackere, 2007, pp. 81-99). MindsEater focuses on serving specific customer segments - on the one hand those ordering specific services (mainly companies from the small and medium enterprises sector), and on the other,

1 The author is a co-founder of the concept of the business model for the analysed enterprise. Due to the confidentiality of certain information, the paper presents only certain aspects, which exemplify an innovative approach to create a business model on the demanding foreign market. 
ICT and software projects performers (usually specialized companies from the IT sector). MindsEater, therefore, acts according to a diversified model. Each of these customer groups has different needs and problems, and therefore each of the segments requires a slightly different value proposition. Moreover, value proposition, distribution channels and customer relationships shall all be adapted to specific requirements of the representatives of these particular segments.

Modern technology and software solutions offered by MindsEater on the British market must differentiate, above all, with quality aspects such as expertise, experience, competence, service customization, customer recommendations and positively evaluated international projects, which had been previously implemented. Value proposition offered by the enterprise can satisfy both the new and previously undiagnosed set of needs (due to a lack of an appropriate offer on the market), and expand the existing needs of specific customers through a dedicated, personalized offer. Key activities taken by the company on the British market are connected with the innovative platform ITProjectPlace (2017). It is a new application and a dedicated product for innovative ICT communities. An innovative community involves contractors who realize IT orders, and who can search online for clients in foreign markets and, using shared platform functionality, conduct cooperation on ongoing projects using appropriate tools dedicated to this type of activity.

The concept of the individualization of products and services as well as the co-creation of the offer by customers, and the possibility of assessment at various stages of formation of a particular service are all desired by the discerning business customers on the British market. The designed business model functions well only if the company undertakes key actions necessary to create and present a value proposition to its target customers, build and maintain relationships with them, and ultimately generate profits.

\section{Conclusions and Recommendations}

By engaging in creating and implementing innovative business models, a company must take into account the context of micro-business as well as social, economic and political environment in which it operates. An effective management of the business model is a necessary factor. It requires constant monitoring of all elements of the model and observing competitive environment. It is important to diagnose current market and acquire information about factors that may affect a company's operations in the long term as well as the evolution of model elements according to the market reaction. This should contribute to the integration of pre-existing solutions in such a way as to achieve synergies and avoid conflicts or be able to solve them efficiently.

The team of MindsEater should constantly evaluate the effectiveness of their business model and work on generating appropriate value propositions. They should always look for and address the unmet needs of customers and use them 
as an axis to build sustainable business models. It is worth ensuring that there are appropriate mechanisms for obtaining feedback and recognizing the early signals of shifts in market trends. Moreover, it is important to skillfully manage uncertainties and use project-based approach, involving the search for a number of different solutions, and their testing by a group of target customers. The lack of adaptation of a profitable model and break through solutions to changes in the competitive environment may cause difficulty in maintaining market position. As the environmental conditions change, business models require adaptation to new challenges and expectations. Business models are a firm' strategic response to their environment.

Smooth functioning in business ecosystem requires taking flexible actions. It is worth experimenting with different types of relationships with new business partners on the British market to seek alternative sources of income, looking for new opportunities beyond the current customer base and observing the potential role of new distribution channels. On the basis of additional information about the supported market, it is possible to successfully improve strategy and increase profitability. An innovative approach to the development, implementation and modification of the business model should be a common method of ensuring sustainable development.

Innovative young enterprises like MindsEater need to create appropriate methods for the presentation of their impact on the environment and focus on greater accountability for their activities. It requires adaptation in the business model concerning introduction of responsibility for the activities with the environment.

\section{References}

Afuah, A., \& Tucci, C.L. (2003). Internet business models and strategies. Boston: McGraw Hill.

Alt, R., \& Zimmermann, H. (2001). Preface: introduction to special section business models. Electronic Markets, 11(1). doi:10.1080/713765630.

Amit, R., \& Zott, C. (2001). Value creation in E-business. Strategic Management Journal, 22(6-7). doi:10.1002/smj.187.

Andries, P., \& Debackere, K. (2007). Adaptation and performance in new businesses: understanding the moderating effects of independence and industry. Small Business Economics, 29(1-2). doi:10.1007/s11187-005-5640-2.

Applegate, L.M. (2001). Emerging E-business models. Harvard Business Review, $79(1)$.

Badzińska, E. (2017). Exploring the concept of born to be global in the context of technological entrepreneurship. Journal of Creativity and Business Innovation, 3.

Berger, I.E., Cunningham, P.H., \& Drumwright, M.E. (2007). Mainstreaming corporate social responsibility: developing markets for virtue. California Management Review, 49(4). doi:10.2307/41166409. 
Betz, F. (2002). Strategic business models. Engineering Management Journal, 14(1). doi:10.1080/10429247.2002.11415145.

Brews, P.J., \& Tucci, C.L. (2003). Building internet generation companies: lessons from the front lines of the old economy. Academy of Management Executive, 17(4).

Chesbrough, H., \& Rosenbloom, R.S. (2002). The role of the business model in capturing value from innovation: evidence from Xerox corporation's technology spin-off companies. Industrial and Corporate Change, 11(3). doi:10.1093/icc/11.3.529.

Claydon, J. (2011). A new direction for CSR: the shortcomings of previous CSR-models and the rationale for a new model. Social Responsibility Journal, 7(3). doi:10.1108/17471111111154545.

Czakon, W. (2013). Zastosowanie studiów przypadku w badaniach nauk o zarządzaniu. In W. Czakon (ed.), Podstawy metodologii badań w naukach o zarządzaniu. Warszawa: Wolters Kluwer Business.

Dubosson-Torbay, M., Osterwalder, A., \& Pigneur, Y. (2001). E-business model design, classification and measurements. Thunderbird International Business Review, 44(1). doi:10.1002/tie.1036.

Dyer, J., \& Nobeoka, K. (2000). Creating and managing a high performance knowledge-sharing network: the Toyota case. Strategic Management Journal, 21(3). doi:10.1002/(SICI)1097-0266(200003)21:3<345::AID-SMJ96>3.0.CO;2-N.

Foss, N.J., \& Klein, P.G. (2012). Organizing entrepreneurial judgment: a new approach to the firm. Cambridge: Cambridge University Press.

Gordijn, J., Akkermans, J., \& Van Vliet, J. (2001). Designing and evaluating E-business models. IEEEIntellectual Systems, 16(4). doi:10.1109/5254.941353.

Hamel, G. (2001). Leading the revolution. Boston: Harvard Business School Press.

ITProjectPlace. (2017). Retrieved 05.05.2017 from www.itprojectplace.eu.

Jabłoński, A. (2009). Model zrównoważonego biznesu a bezpieczeństwo biznesowe przedsiębiorstwa. Zeszyty Naukowe Wyższej Szkoty Humanitas. Zarządzanie, 2.

Jick, T.D. (1979). Mixing qualitative and quantitative methods: triangulation in action. Administrative Science Quarterly, 24(4). doi:10.2307/2392366.

Konczal, E.F. (1975). Models are for managers, not mathematicians. Journal of Systems Management, 26(1).

Magretta, J. (2002). Why business models matter. Harvard Business Review, 80(5).

Markides, C. (1999). A dynamic view of strategy. Sloan Management Review, 40(3).

Maxwell, J.A. (2005). Qualitative research design: an interactive approach (2nd edition). Thousand Oaks: Sage Publications.

Merriam, S.B. (1998). Qualitative research and case studies applications in education. San Francisco: Jossey-Bass Publications. 
Morris, M., Schindehutte, M., \& Allen, J. (2005). The entrepreneur's business model: toward a unified perspective. Journal of Business Research, 58(6). doi:10.1016/j.jbusres.2003.11.001.

Nacu, C.M., \& Avasilcai, S. (2014). Technological ecopreneurship: conceptual approaches. Procedia - Social and Behavioral Sciences, 124. doi:10.1016/j. sbspro.2014.02.481.

Osterwalder, A., \& Pigneur, Y. (2003). Towards strategy and information systems alignment through a business model ontology. Retrieved 05.05.2017 from http://citeseerx.ist.psu.edu.

Osterwalder, A., \& Pigneur, Y. (2010). Business model generation. New Jersey: John Wiley \& Sons.

Osterwalder, A., Pigneur, Y., \& Tucci, C.L. (2005). Clarifying business models: origins, present, and future of the concept. Communications of the AIS, 16(1).

Porter, M.E., \& Kramer, M.R. (2006). Strategy and society: the link between competitive advantage and corporate social responsibility. Harvard Business Review, 84(12).

Raczkowski, K., Sułkowski, Ł., \& Fijałkowska, J. (2016). Comparative critical review of Corporate Social Responsibility Business Management Models. International Journal of Contemporary Management, 15(2). doi:10.4467/24498939IJCM.16.014.5554.

Salerno, M.S., de Vasconcelos Gomes, L.A., da Silva, D.O., Bagno, R.B., \& Freitas, S.L.T.U. (2015). Innovation processes: which process for which project? Technovation, 35. doi:10.1016/j.technovation.2014.07.012.

Seddon, P.B., \& Lewis, G.P. (2004). The case for viewing business models as abstraction of strategy. Communications of the Association for Information Systems, 13.

Sułkowski, Ł., \& Fijałkowska, J. (2013). Corporate social responsibility and intellectual capital interaction and voluntary disclosure. Studia Ekonomiczne. Zeszyty Naukowe Uniwersytetu Ekonomicznego w Katowicach, 150.

Szirmai, A., Naude, W., \& Goedhuys, M. (2011). Entrepreneurship, innovation, and economic development: an overview. Oxford: Oxford University Press.

Szpringer, W. (2012). Innowacyjne modele e-biznesu - perspektywy rozwojowe. Problemy Zarzązania, 10(3). doi:10.7172/1644-9584.38.5.

Timmers, P. (1998). Business models for electronic markets. Electron Commercial Europe, 8(2). doi:10.1080/10196789800000016.

Voelpel, S.C., Leibold, M., \& Tekie, E.B. (2004). The wheel of business model reinvention: how to reshape your business model to leapfrog competitors. Journal of Change Management, 4(3). doi:10.1080/1469701042000212669.

Weill, P., \& Vitale, M.R. (2001). Place to space: migrating to E-business models. Boston: Harvard Business School Press.

Yin, R.K. (1984). Case study research: design and methods. Thousand Oaks: Sage Publications.

Zott, C., \& Amit, R. (2007). Business model design and the performance of entrepreneurial firms. Organization Science, 18(2). doi:10.1287/orsc.1060.0232. 


\section{Acknowledgements}

Author contributions: author has given an approval to the final version of the article.

Funding: this research was undertaken as part of the (Research of economic problems of the polish economy) project and was fully funded by the Poznan University of Technology, Faculty of Engineering Management of the statutory sources (503217/11/143/DSPB/0609).

Supplementary information: author acknowledge following people for help with the preparation of the article: to the CEO of MindsEater.

Note: the results of this study were presented at 9th International Conference on Applied Economics Contemporary issues in Economy (June 22-23, Torun, Poland). 


\section{Appendix}

Table 1 .

Varying definitions of business model applied in selected research

\begin{abstract}
Value / customer
oriented definition

A mediating construct between technology and economic value, its role is in capturing value from innovation and delivering it to customers (Chesbrough \& Rosenbloom, 2002, pp. 529-555).

Generally understood as a view of the firm's logic for creating and commercializing value and product/service (Timmers, 1998, pp. 1-6; Markides, 1999, pp. 55-63; Dubosson-Torbay et al., 2001, pp. 5-23; Osterwalder et al., 2005, pp. 1-25), also in the e-business (Amit \& Zott, 2001, pp. 484-493).
\end{abstract}

The main role of the business model is to find and design a promising business concept. It is the way of value creation for the client and the owners of the business unit (Applegate, 2001, pp. 79-87; Afuah \& Tucci, 2003; Hamel, 2001; Weill \& Vitale, 2001; Osterwalder et al., 2005, pp. 1-25).

Innovative business models should adequately suit the needs of contemporary business practice (Raczkowski et al., 2016, pp. 123-150).
Activity / role and profit oriented definition

The business model describes the rules of business operation and gives an explanation of the competitive advantage sources (Porter \& Kramer, 2006, pp. 78-92).

A system that shows how the pieces of a business fit together (Magretta, 2002, pp. 86-92). Business models change rapidly, which creates the need to find a shared way of describing them (Hamel 2001).

Estimation of the cost structure and profit potential of producing the offering; other financial outcomes of the company like revenues or bottom-line (Timmers, 1998, pp. 1-6; Markides, 1999, pp. 55-63; Chesbrough and Rosenbloom, 2002, pp. 529-555, Dubosson-Torbay et al., 2001, pp. 5-23; Afuah \& Tucci, 2003; Weill \& Vitale, 2001; Alt \& Zimmerman, 2001, pp. 3-9; Betz, 2002, pp.

$$
\text { 21-24). }
$$

Business models are a firm' strategic response to their environment and require adaptation to new challenges and expectations (Voelpel et al., 2004, pp. 259-276; Morris et al., 2005, pp. 726-735; Zott \& Amit, 2007, pp. 181-199).
Concept / tool oriented definition

A conceptual tool containing a set of objects, concepts and their relationships with the objective to express the business logic of a specific firm (Osterwalder et al., 2005, pp. 1-25).

The business model serves as a building plan that allows designing and realizing the business structure and systems that constitute the com-

pany's economic, operational, and strategic form (Morris et al., 2005, pp. 726-735; Osterwalder et al., 2005, pp. 1-25).

An abstraction of a firm's strategy that may potentially apply to many firms (Seddon \& Lewis, 2004, pp. 427-442); a dynamic view of strategy (Markides, 1999, pp. 55-63).

An abstract concept that allows describing and giving an idea of what a business does for a living (Timmers 1998, pp. 1-6; Magretta, 2002, pp. 86-92).

A holistic concept

Text Many authors emphasize that a business model needs to be understood as a much more holistic concept that embraces all such elements as pricing mechanisms, customer relationships, partnering, and revenue sharing (Timmers, 1998, pp. 1-6; Dubosson-Torbay et al., 2001, pp. 5-23; Weill \& Vitale, 2001; Alt \& Zimmerman, 2001, pp. 3-9; Betz, 2002, pp. 21-24; Afuah \& Tucci, 2003; Osterwalder \& Pigneur, 2003, pp. 1-25; 2010). A new direction of business activities in a 'responsible' way

This responsibility embraces new fields: actions towards creation of a more comfortable workplace, taking care of the environment and strengthening relations with shareholders (Berger et al., 2007, pp. 132-157; Claydon, 2011, pp. 405-420; Raczkowski et all., 2016, pp. 123-150). It is related to the intellectual capital of companies, refers to the relations inside the company, contacts with stakeholders, and impact on the environment (Sulkowski \& Fijałkowska, 2013, pp. 60-75).

Source: Own elaboration. 


\section{Table 2.}

\section{The concept of business model for the analyzed IT enterprise}

\begin{tabular}{|c|c|}
\hline Building blocks & Explanation \\
\hline \multirow{2}{*}{$\begin{array}{l}\text { customer } \\
\text { segments }\end{array}$} & - B2B Segment: small and medium-sized enterprises on the UK market \\
\hline & - B2C Segment: programmers, IT professionals, freelancers \\
\hline $\begin{array}{l}\text { value } \\
\text { proposition }\end{array}$ & $\begin{array}{l}\text { - original and unconventional ICT solutions, high quality services, dedicated offers for the B2B } \\
\text { market, individualization and customization, lower cost of services }\end{array}$ \\
\hline \multirow[t]{2}{*}{ channels } & - own and direct: Internet sales, distribution network, representative office \\
\hline & - affiliate and indirect: a foreign agent, a local distributor, joint venture \\
\hline \multirow{2}{*}{$\begin{array}{l}\text { customer } \\
\text { relationships }\end{array}$} & - a prerequisite for success customer satisfaction \\
\hline & - direct support, dedicated guardian, value co-creation, automated service \\
\hline \multirow{2}{*}{$\begin{array}{l}\text { revenue } \\
\text { streams }\end{array}$} & - transaction revenue and periodic revenue \\
\hline & $\begin{array}{l}\text { - sales of IT services, subscription fee for the use of certain services, commission from interme- } \\
\text { diation, after-sales services and advertising fees }\end{array}$ \\
\hline \multirow[t]{2}{*}{ key resources } & $\begin{array}{l}\text { - intellectual assets: knowledge, experience, creativity, competence of management, manage- } \\
\text { ment style and leadership, organizational culture }\end{array}$ \\
\hline & - material resources: developer server, IT infrastructure \\
\hline key activities & $\begin{array}{l}\text { - copyright, advanced technology and software solutions, professional IT consulting, imple- } \\
\text { mentation and after-sales support }\end{array}$ \\
\hline \multirow[t]{2}{*}{ key partners } & $\begin{array}{l}\text { - specialized companies, micro and small enterprises offering technology and programming, } \\
\text { graphic and ICT services }\end{array}$ \\
\hline & - consulting companies in the field of marketing, finance, business law \\
\hline cost structure & $\begin{array}{l}\text { - fixed costs: maintaining own intellectual, administrative, technological infrastructure and of- } \\
\text { fice resources }\end{array}$ \\
\hline & _ variable costs: salaries for business partners for specialist services \\
\hline
\end{tabular}

Source: Own research findings. 